\title{
PEMULIHAN TRAUMA PSIKOSOSIAL PADA PEREMPUAN KORBAN KEKERASAN SEKSUAL DI YAYASAN PULIH
}

\author{
Khusnul Fadillah \\ Panti Sosial Tresna Werdha Budi Mulia 03 Margaguna \\ Email: khusnulfadillahm@gmail.com
}

Received: 28th July 2018; Revised: 18th September 2018; Accepted: 15th December 2018

\begin{abstract}
One form of crime against humanity is rape, sexual harassment, sexual slavery or other forms of sexual violence where the victims are often women. In dealing with cases of sexual violence, not only do we depend on government regulations that provide severe penalties for the perpetrators, but also the role of the surrounding community who care about social problems, especially community institutions. The role of institutions is very much needed in handling victims of sexual violence which have severe impacts on both children and adults. With this this set of background, Pulih Foundation was born as a psychological institution that provides counseling and assistance services for the recovery victims of sexual violence. This study aims to reveal how the stages and efforts to recover trauma of sexual violence victims to recover from the violence effects. This research is a qualitative research with a descriptive research type. Data collection consists of interview, observation and documentation. The selection of informants uses a purposive sampling technique. The research results show that Pulih Foundation has been making efforts to restore vvictims of sexual violence by providing assistance and counseling. In the recovery effort, victims of sexual violence go through the following stages: emotional stages such as the denial stage, the anger stage, the depression stage and the offer stage before finally reaching the acceptance stage.
\end{abstract}

Keywords: Recovery, Victims of Sexual Violence, Pulih Foundation.

Abstrak. Salah satu bentuk kejahatan terhadap kemanusiaan berupa pemerkosaan, pelecehan seksual, perbudakan seksual atau bentuk-bentuk kekerasan seksual lainnya yang korbannya sering kali adalah perempuan. Dalam menangani kasus kekerasan seksual tidak hanya perpangku tangan mengandalkan peraturan pemerintah yang memberikan hukuman berat untuk para pelaku, tetapi juga peran masyarakat sekitar yang peduli akan masalah sosial terutama lembaga-lembaga masyarakat. Peranan lembaga sangat dibutuhkan dalam penanganan korban kekerasan seksual yang menimbulkan dampak berat baik pada anak maupun pada orang dewasa. Dengan adanya permasalahan tersebut Yayasan Pulih lahir sebagai lembaga psikologi yang memberikan layanan konseling dan pendampingan untuk pemulihan korban kekerasan seksual. Penelitian ini bertujuan mengungkap bagaimana tahapan dan upaya pemulihan trauma kepada korban kekerasan seksual untuk pulih dari dampak kekerasan tersebut. Penelitian ini menggunakan metodelogi penelitian kualitatif dengan jenis penelitian deskriptif. Pengumpulan data dilakukan dengan teknik wawancara, observasi dan dokumentasi. Pemilihan informan menggunakan teknik purposive sampling. Hasil Penelitian menunjukkan itu Yayasan Pulih melakukan upaya pemulihan untuk korban kekerasan seksual dengan memberikan pendampingan serta konseling. Pada upaya pemulihan, korban kekerasan seksual melewati tahapan sebagai berikut: tahapan emosi seperti tahap penyangkalan, tahap kemarahan, tahap depresi dan tahap penawaran sebelum akhirnya mencapai tahap penerimaan.

Kata Kunci: Pemulihan, Korban Kekerasan Seksual, Yayasan Pulih. 


\section{Pemulihan Trauma Psikososial pada Perempuan \\ Korban Kekerasan Seksual di Yayasan Pulih}

- Khusnul Fadillah

\section{Pendahuluan}

Kejahatan merupakan fenomena yang sering terjadi di lingkungan masyarakat sehingga menjadi perbincangan masyarakat baik secara langsung maupun tidak langsung seperti melalui media elektronik maupun cetak, kejahatan sebagai salah satu bentuk problema sosial yang ada di masyarakat. Kejahatan menurut R. Soesilo menjadi dua sudut pandang yaitu sudut pandang yuridis dan sosiologis. Dalam sudut pandang yuridis menjelaskan bahwa kejahatan adalah suatu tingkah laku yang bertentangan dengan undang- undang sedangkan sudut pandang sosiologis kejahatan adalah perbuatan atau tingkah laku yang selain merugikan si penderita (korban) juga sangat merugikan masyarakat yaitu berupa hilangnya keseimbangan, ketentraman dan ketertiban (Soesilo, 1985).

Berdasarkan Undang-undang Pengadilah Hak Asasi Manusia Nomor 26 tahun 2000 pada pasal 7 menjelaskan bahwa salah satu pelanggaran hak asasi manusia yang berat adalah kejahatan terhadap kemanusiaan. Dijelaskan kembali di pasal 9 dalam undang - undang tersebut bahwa kejahatan terhadap kemanusiaan adalah salah satu perbuatan yang dilakukan sebagai bagian dari serangan yang meluas atau sistematik yang diketahuinya bahwa serangan tersebut ditujukan secara langsung terhadap penduduk sipil, salah satunya berupa bentuk-bentuk kekerasan seksual lainnya yang setara meliputi perkosaan, perbudakan seksual, pelacuran secara paksa, pemaksaan kehamilan, pemandulan atau sterilisasi secara paksa dan lainnya.

Selama periode Tahun 2013-2015, jumlah kejadian kejahatan atau tindak kriminalitas di Indonesia berfluktuasi. Menurut data di Biro Pembinaan dan Operasional (Sub Direktorat Statistik dan Keamanan, 2016), Mabes Polri memperlihatkan jumlah kejadian kejahatan (crime total) pada tahun 2013 sebanyak 342.084 kasus, menurun menjadi sebanyak 325.317 kasus pada tahun 2014 dan meningkat pada tahun 2015 menjadi 352.936 kasus. Sementara itu, jumlah orang yang berisiko terkena tindak kejahatan (crime rate) setiap 100.000 penduduk diperkirakan sebanyak 140 orang pada tahun 2013, 131 orang pada tahun 2014, dan 140 orang pada tahun 2015.

Di Indonesia berbagai macam kejahatan terjadi pada lingkungan masyarakat dari kejahatan skala kecil sampai dengan kejahatan skala besar. Salah satu bentuk kejahatan terhadap kemanusiaan adalah kejahatan bentuk kekerasan seksual dalam Undang-Undang Pengadilan Hak Asasi Manusia Nomor 
26 tahun 2000 pada pasal 9 berupa perkosaan, perbudakan seksual, pelacuran secara paksa, pemaksaan kehamilan, pemandulan atau sterilisasi secara paksa atau bentuk-bentuk kekerasan seksual lainnya.

Korban dari kejahatan kekerasan seksual banyak terjadi pada perempuan, hal ini dikarenakan perempuan sangat rentan mendapat tindak kekerasan seksual. Kekerasan seksual sendiri merupakan isu penting dan rumit dari seluruh peta kekerasan terhadap perempuan karena ada dimensi yang sangat khas bagi perempuan. Persoalan ketimpangan relasi kuasa antara pelaku dan korban adalah akar kekerasan seksual terhadap perempuan. Kekerasan terhadap perempuan menurut (Amora, 2003) adalah setiap tindakan berdasarkan gender yang menyebabkan kerugian atau penderitaan fisik, seksual atau psikologis, termasuk ancaman untuk melaksakan tindakan tersebut dalam kehidupan masyarakat dan pribadi.

Peristiwa kekerasan seksual seringkali juga dikaitkan pada penilaian perempuan yang sebagai korban dituduh sebagai penyebab atau pemberi peluang terjadinya kekerasan seksual karena cara berpakaiannya, bahasa tubuhnya, cara ia berelasi sosial, status perkawinannya, pekerjaannya, atau karena keberadaannya pada sebuah waktu atau lokasi tertentu. Dalam konteks ini pula, korban kerap dituduh membiarkan peristiwa kekerasan tersebut terjadi ketika ia dianggap tidak berupaya untuk melawan pelaku, menempatkan dirinya terus-menerus gampang disentuh pelaku, ataupun terbuai dengan iming-iming pelaku.

Upaya menangani kasus kekerasan seksual, mengandalkan peraturan pemerintah yang memberikan hukuman berat untuk para pelaku saja tidak cukup. Karena seberat apapun undang-undang yang digunakan, jika pelaporannya saja sulit akan menambah permasalahan. Hal ini disebabkan masih banyaknya korban kesulitan untuk melaporkan kasus yang terjadi kepada mereka dan kurangnya pengetahuan yang didapatkan oleh korban. Oleh karena itu korban tidak tahu harus ke mana untuk melapor serta mendapatkan pendampingan hokum, selain itu mereka juga mendapat intimidasi dari pelaku.

Jadi pada kasus kekerasan seksual ini bukan hanya partisipasi dari pemerintah saja tetapi dari masyarakat sekitar yang peduli akan masalah sosial terutama lembaga-lembaga masyarakat. Peranan lembaga sangat dibutuhkan untuk berpartisipasi dalam penanganan kasus korban kekerasan seksual karena kekerasan seksual cenderung menimbulkan dampak traumatis baik pada anak 


\section{Pemulihan Trauma Psikososial pada Perempuan \\ Korban Kekerasan Seksual di Yayasan Pulih}

Khusnul Fadillah

(Illenis \& Handadari, 2011).

Sesuai dengan Undang-Undang Republik Indonesia Nomor 23 Tahun 2004 Pasal 39 Tentang Penghapusan Kekerasan Dalam Rumah Tangga yang menyebutkan "Untuk kepentingan pemulihan, korban dapat memperoleh pelayanan dari, tenaga kesehatan, pekerja sosial, relawan pendamping; dan/ atau pembimbing rohani".

Salah satu lembaga yang mendampingi korban kekerasan adalah Yayasan Pulih. Yayasan Pulih sebagai pusat penguatan psikososial terhadap penyintas trauma kekerasan dan bencana memiliki kepedulian untuk membantu penyintas dalam konteks pemulihan psikososial. Untuk itu, Yayasan Pulih mengembangkan rangkaian program bagi korban maupun pendamping kekerasan struktural. Sebagaimana misi Yayasan Pulih untuk pendidikan dan penyadaran publik kepada kelompok masyarakat, lembaga-lembaga, dan para pengambil keputusan tentang pencegahan dan penanganan kekerasan berdasarkan pemulihan trauma dan intervensi psikososial. Maka Yayasan Pulih memberikan pelatihan-pelatihan dan menjadi narasumber tekait isu tersebut. Yayasan Pulih sangat terbuka dalam menerima klien dari berbagai macam latar belakang dari laki-laki, perempuan, anak-anak, remaja, dewasa, secara individual, keluarga, maupun kelompok. Selain menerima klien datang langsung, Yayasan Pulih juga menerima rujukan dari institusi atau lembaga lain yang membutuhkan layanan klinik Pulih.

Yayasan Pulih juga memberikan pelayanan untuk pemulihan korban kekerasan, termasuk didalamnya korban kekerasan seksual. Selain itu Yayasan Pulih memang kompeten dibidangnya dan sudah banyak menangani kasus serta menjadi rujukan instansi lain seperti LBH Apik Jakarta dan juga menjalin kerjasama dengan KPAI, UNICEF, ILO dan lainnya. Namun dalam pemulihan korban kekerasan seksual ini di Yayasan Pulih belum menjalin kerjasama dengan pekerja sosial dalam melakukan pendampingan terhadap korban kekerasan seksual.

\section{Metode}

Pendekatan yang digunakan dalam penelitian ini adalah pendekatan kualitatif, yaitu penelitian yang menekankan pada kualitas dalam sebuah penelitian. Penelitian ini juga dimaksudkan untuk mengetahui informasi lebih mendalam melalui observasi dan wawancara kepada informan (Sugiyono, 
2010). Jenis penelitian yang penulis gunakan dalam penelitian ini adalah jenis penelitian deskriptif. Penelitian deskriptif yaitu penelitian yang menggambarkan atau melukiskan situasi tertentu berdasarkan data yang diperoleh di lapangan secara terperinci sesuai dengan fokus penelitian yang telah ditetapkan, (Moleong, 2004).

Penelitian menggunakan jenis penelitian descriptive dengan alasan peneliti akan menggambarkan proses pemulihan yang ada di Yayasan Pulih terhadap perempuan yang menjadi korban kekerasan seksual dengan terperinci sesuai yang terjadi di lapangan. Laporan penelitian akan berisi kutipan kutipan data untuk memberi gambaran penyajian laporan tersebut. Data tersebut berasal dari naskah wawancara secara langsung, catatan lapangan atau memo dan dokumentasi lainnya, ( Gulo, 2002).

Peneliti mengambil tempat penelitian yang dilakukan di Yayasan Pulih. Alasan peneliti mengambil Yayasan Pulih sebagai tempat penelitian karena Yayasan Pulih merupakan lembaga yang bergerak dalam bidang pemulihan diri terutama bagi yang mengalami dampak psikologis akibat peristiwa kekerasan dan sesuai dengan topik penelitian ini. Waktu penelitian dilaksanakan pada bulan November 2016 sampai dengan bulan Februari 2018.

Teknik pengumpulan data, peneliti menggunkan teknik pengumpulan data seperti wawancara, observasi wawancara kepada infoman. Kemudian dari wawancara kita bisa oleh data tersebut menjadi sebuah data yang utuh untuk melihat hasil penelitian yang dilakukan. Dalam penelitian ini pemilihan informan menggunakan teknik purposive sampling. Teknik purposive sampling bertujuan di mana informan dipilih berdasarkan pertimbangan tertentu dan dianggap sebagai orang orang yang tepat memberikan informasi yang sesuai dengan kebutuhan penelitian (Irawan, 2004).

Konsep sampel dalam penelitian kualitatif berkaitan erat dengan bagaimana memilih informan misalnya orang tersebut dianggap paling tahu tentang apa yang kita harapkan atau mungkin dia sebagai penguasa sehingga akan mempermudah peneliti menjelajahi objek atau situasi sosial yang diteliti. Hal terpenting disini bukan jumlah informannya, melainkan potensi dari setiap kasus untuk dapat memberikan secara teoritis mengenai aspek yang dipelajari (Sugiyono, 2010).

Pada saat menganalisis data hasil wawancara, peneliti mengamatinya secara detail dan dilakukan secara berulang dari awal sampai akhir, kemudian 


\section{Pemulihan Trauma Psikososial pada Perempuan \\ Korban Kekerasan Seksual di Yayasan Pulih}

- Khusnul Fadillah

menyimpulkannya. Setelah itu menganalisa kategori-kategori yang terlihat pada data data tersebut. Analisa data melibatkan upaya mengidentifikasi suatu objek dan peristiwa. Katagori dari analisa data diperoleh berdasarkan fenomena yang terlihat pada tempat penelitian tersebut. Setelah data dianalisa kemudian disajikan dalam tulisan-tulisan.

\section{Hasil dan Diskusi}

Pada bagian ini, peneliti akan memaparkan hasil temuan di Yayasan Pulih mengenai pemulihan trauma psikososial yang terjadi pada perempuan korban kekerasan seksual. Adapun pemulihan trauma yang akan dianlisis oleh peneliti pada perempuan korban kekerasan seksual yang terdapat di Yayasan Pulih berupa upaya pemulihan trauma dalam mengatasi korban kekerasan seksual serta menganlisa tahapan apa saja yang terjadi pada korban kekerasan seksual yang ditangani oleh Yayasan Pulih. Berikut temuan dan hasil anlisa peneliti dalam penelitian ini.

\section{Upaya Pemulihan pada Perempuan Korban Kekerasan Sekual di Yayasan Pulih}

Kekerasan seksual merupakan kejahatan yangsering terjadi dilingkungan masyarakat terutama pada perempuan baik pada usia anak-anak, remaja maupun dewasa yang menjadi korbannya. Dalam kasus kekerasan seksual ini, kebanyakan masyarakat hanya melihat dan fokus kepada pelaku kekerasan seksual seperti hukuman yang akan didapatkan yang sesuai yang sesuai dengan perbuatannya, maka permasalahan sudah dianggap selesai. Kenyataannya, masyarakat tidak seharusnya hanya melihat kepada pelaku tetapi juga kepada korban kekerasan seksual tersebut. Hal ini karena kekerasan seksual akan memberikan dampak trauma dan luka sendiri bagi korban tersebut.

Seperti yang dikatakan oleh Ibu Ika selaku psikolog di Yayasan Pulih yang berkata:

"Kasus kekerasan seksual itu kan memang sesuatu yang cenderung dampaknya besar ke korbannya. Karena kekerasan seksual itu berarti seseorang memasuki ranah pribadi kita. Sehinga bener-bener seperti kita tidak ada harganya karena seseorang itu masuk keranah pribadi kita."

Kekerasan seksual memiliki dampak yang besar ke korban kekerasan seksual, walaupun ada beberapa korban yang tidak menunjukan hal yang sama. Seperti yang dikatakan ibu Ika psikolog Yayasan Pulih sebagai berikut: 


\begin{abstract}
"Dampak sebenernya tergantung kliennya, ada yang dia kacau banget, nangis-nangis gitu, ada juga yang biasa aja ga kelihatan ada masalah. Akan tetapi itulah kejamnya masyarakat menilai dari tampilan luar, ketika misalnya melilhat orang yang biasa aja dia malah di bilang, ah lu mah gada masalah, cuma ngada-ngada doang diperkosa, karena ya itu orang ngarepnya ketika seseorang menjadi korban kekerasan seksual, dia menjadi depresi gitu, kalo keliatan baik-baik aja dibilang boong. Padahalga jugakan, tergantung karakternya. Kalo kita ngomong psikologi ada orang yang delay responnya, misalnya pas awal dia biasa-biasa aja kemudian beberapa lama kemudian baru muncul. Ada juga orang yang memang sangat ekspresif, ada yang langsung depresi, pokoknya beda-beda".
\end{abstract}

Berdasarkan hasil wawancara dengan Ibu Ika selaku psikolog di Yayasan Pulih menjelaskan bahwa kondisi korban kekerasan seksual terhadap dampak yang diderita itu tergantung sikap dan perilaku dari masing-masing individu tersebut. Misalnya, ada korban yang ekspresif dalam mengungkapkan perasaan mereka terhadap dampak yang diderita da nada juga yang takut dalam mengungkapkan dampak yang dialami dari kasus kekerasan seksual. Dalam hal ini, jika korban kekerasan seksual yang terlihat baik dari tampilan luar saja belum tentu secara psikis juga dalam keadaan baik.

Untuk mengatasi dampak yang terjadi pada korban kekerasan seksual melalui upaya pemulihan, merupakan aspek yang penting untuk penanganan kasus kekerasan seksual. Pemulihan yang diberikan pada korban kekerasan seksual sebagai suatu usaha untuk menyelesaikan masalah dan dampak negatif yang menimpa korban agar bisa mendapatkan kembali kendali atas hidupnya.

Berdasarkan Peraturan Pemerintah Nomor 4 tahun 2006 Pasal 4 tentang Penyelenggaraan dan Kerjasama Pemulihan Korban Kekerasan dalam Rumah Tangga yang menyebutkan, "Penyelengaraan kegiatan pemulihan korban meliputi pelayanan kesehatan, pendampingan korban, konseling, bimbingan rohani dan resosialisasi." Yayasan Pulih sebagai lembaga non profityang memiliki misi untuk mengutamakan penguatan psikosial untuk rakyat bagi penanganan kekerasan, maka Yayasan Pulih melakukan upaya pemulihan untuk memberikan pelayanan terhadap korban kekerasan seksual sebagai upaya pemulihan dalam mengatasi dampak negatif yang diterima oleh korban tersebut. Pelayanan yang diberikan oleh Yayasan Pulih berupa klinik pulih. Klinik pulih dimaksudkan untuk memberikan layanan psikologis bagi semua orang yang membutuhkan terutama bagi yang mengalami dampak psikologis akibat peristiwa kekerasan 


\section{Pemulihan Trauma Psikososial pada Perempuan \\ Korban Kekerasan Seksual di Yayasan Pulih}

- Khusnul Fadillah

dan pengalaman traumatis lainnya.

Pelayanan yang diberikan oleh Yayasan Pulih berdasarkan hasil wawancara di atas berupa konseling psikologis dalam bentuk individu, pasangan, keluarga maupun kelompok yang dilakukan secara langsung antara psikolog dengan klien. Konseling tidak hanya dilakukan secara langsung saja tetapi juga dapat dilakukan melalui $e$-mail. Selain konseling psikolog, pelayanan yang diberikan adalah pemeriksaan psikologis, saksi ahli pendampingan psikologis, tes psikologis. Pelayanan ini juga dapat dilakukan sebagai upaya pemulihan korban kekerasan seksual.

Dalam penelitian ini, peneliti menganalisa upaya pemulihan atau pemulihan yang dilakukan oleh Yayasan Pulih terhadap korban kekerasan seksual berdasarkan Peraturan Pemerintah Nomor 4 Tahun 2006 pasal 4 tentang Penyelenggaraan dan Kerja Sama Pemulihan Kekerasan dalam Rumah Tangga menyatakan bahwa penyelenggara kegiatan pemulihan korban meliputi: Pendampingan korban, identifikasi masalah, penerapan, evaluasi dan tindak lanjut, dan pengakhiran.

Proses pemulihan korban kekerasan seksual melewati beberapa tahapan, maka untuk menganalisa tahapan proses pemulihan penulis akan menggunakan lima tahap kesedihan yang umum digunakan sebagai teori pemulihan diri dan pada korban tidak selalu melewati setiap tahapan (Illenis \& Handadari, 2011).

Denial (Penangkalan), merupakan fase dimana korban menyangkal bahwa mengalami tindak kekerasaan seksual telah terjadi kepada dirinya, hal ini merupakan reaksi utama dari penyakit yang tidak tertolong lagi. Penolakan biasanya pertahanan diri yang bersifat sementara, yaitu dengan perasaan tidak percaya tidak menerima bahwa dirinya mengalami kekerasan seksual.

Tahapan pemulihan yang dilakukan dalam fase penyangkalan yang dialami oleh klien di Yayasan Pulih yaitu membantu klien dalam merubah persepsinya yang kurang tepat atas kejadian yang terjadi padanya.

Anger (Kemarahan), merupakan fase saat korban mengalami tindak kekerasaan seksual menyadari bahwa penolakan tidak dapat dipertahankan lagi. Penolakan muncul dalam rasa marah, benci, dan iri. Ini terjadi karena individu menyadari kenapa dirinya yang mengalami tindak kekerasaan seksual, bukan orang lain. Kemarahannya itu diproyeksikan kepada perawat, dokter, keluarganya, dan juga Tuhan.

Berdasarkan wawancara dengan klien dijelaskan bahwa ketika klien 
atau korban kekerasan seksual dalam fase anger atau kemarahan maka psikolog di Yayasan Pulih melakukan tahapan remembrance and mourning. Hal ini dilakukan oleh psikolog di Yayasan Pulih untuk menjalankan proses pemulihan pada perempuan korban kekerasan seksual yaitu dimana klien diberikan kesempatan untuk dapat melepaskan bebannya dengan berbagi cerita bersama psikolog.

Bargaining (Penawaran) merupakan tahapan ketiga korban tindak kekerasaan seksual mengembangkan harapan sebagai mekanisme pertahanan diri. Individu melakukan tawar menawar dalam arti berharap bahwa trauma ini bisa hilang dengan sendirinya.

Depression (Depresi), merupakan Tahapan keempat pada titik ini, suatu periode depresi atau perubahan mood yang terus menerus. Korban dalam fase ini menjadi pendiam, menolak orang lain, dan banyak merenung. Usaha-usaha untuk memperbaiki dirinya dapat membuat korban masuk kedalam kondisi depresi.

Pada dasarnya, kekerasan seksual yang terjadi pada korban kekerasan seksual dewasa akan menimbulkan dampak negatif bagi dirinya sendiri, salah satunya yakni depresi. Pada proses ini, korban kekerasan seksual tidak hanya menerima dampak secara fisik saja tetapi juga dampak mental yaitu dampak depresi yang ditunjukkan seperti kasus di atas. Dampak mental yang diterima oleh korban kekerasan seksual berasal dari pengaruh luar seperti penilain yang diberikan dari masyarakat di lingkungan korban kekerasan seksual terutama pada kasus kekerasan seksual yang diekspos oleh media.

Acceptance (Penerimaan) merupakan tahap dimana korban mulai mengembangkan rasa damai dan menerima takdir. Pada fase ini perasaaan sakit pada fisik akan menghilang karena sikap kepasrahan individu atas pemahaman yang telah terjadi. Setelah korban mencapai tahap penerimaan, barulah dapat terjadi perkembangan yang positif.

Tahap penerimaan terjadi apabila klien atau korban kekerasan seksual sudah dapat mengendalikan dirinya sendiri, menjalankan aktivitas sehari- hari seperti biasanya tanpa adanya rasa tidak nyaman dan sudah menerima kejadian yang pernah dialaminya. 


\section{Pemulihan Trauma Psikososial pada Perempuan \\ Korban Kekerasan Seksual di Yayasan Pulih}

Khusnul Fadillah

\section{Pekerja Sosial Dengan Kekerasan Seksual Pada Perempuan}

Dalam menangani kasus kekersan seksual untuk pemulihan korban kekerasan seksual pekerja sosial memiliki beberapa peran seperti dalam UU Nomor 4 tahun 2006 bahwa salah satu upaya pemulihan melalui proses pendampingan sosial yang dilakukan oleh pekerja social berdasarkan Peraturan Pemerintah Nomor 4 Tahun 2006 pasal 1 tentang Penyelenggaraan dan Kerja Sama Pemulihan Kekerasan dalam Rumah Tangga menyatakan bahwa petugas penyelenggara pemulihan adalah pekerja sosial dan tenaga kesehatan, relawan pendamping, dan/atau pembimbing rohani, (Peraturan Pemerintah Nomor 4 Tahun 2006).

Hal ini menunjukan bahwa pekerja sosial dapat berkontribusi dalam pemulihan korban kekerasan seksual serta dapat juga berperan sebagai pendamping seperti pada Peraturan Pemerintah Nomor 4 tahun 2006 pasal 5 ayat 1 bahwa Pendampingan korban dilakukan oleh pekerja sosial dan tenaga kesehatan, relawan pendamping, dan/atau pembimbing rohani dengan cara memberikan konseling, terapi, bimbingan rohani dan advokasi guna penguatan dan pemulihan diri korban(Peraturan Pemerintah Nomor 4 Tahun 2006). Selain pendamping bisa juga sebagai konselor seperti diatur pada Peraturan Pemerintah Nomor 4 tahun 2006 pasal 5 ayat 3 pemberian konseling dilakukan oleh pekerja sosial, relawan pendamping, dengan mendengarkan secara empati dan menggali permasalahan untuk penguatan psikologis korban (Peraturan Pemerintah Nomor 4 Tahun 2006).

Dalam memberikan pelayanan pemulihan kepada korban pekerja sosial melakukan upaya menggali permasalahan korban untuk membantu pemecahan masalahnya, memulihkan korban dari kondisi traumatis melalui terapi psikososial, melakukan rujukan ke rumah sakit atau rumah aman atau pusat pelayanan atau tempat alternatif lainnya sesuai dengan kebutuhan.

\section{Kesimpulan}

Berdasarkan penelitian yang telah dilakukan di Yayasan Pulih terdapat dua kesimpulan terkait pemulihan trauma psikososial pada perempuan korban kekerasan seksual adalah sebagai berikut: pertama, Pemulihan merupakan proses perjalanan untuk mencapai kesembuhan dalam mengembalikan keberfungsian klien dalam kehidupan sehari- harinya. Adapun upaya yang dilakukan Yayasan Pulih untuk pemulihan klien diantaranya pendampingan dan 
konseling pada korban kekerasan seksual terutama pada korban perempuan baik usia anak sampai dengan dewasa. Pada proses pemulihan, klien melewati beberapa tahapan emosi yang muncul seperti penyangkalan, kemarahan, penerimaan terdapat pula depresi pada sebagian klien. Tahapan emosi tersebut tidak semua dialami pada satu klien saja tetapi tiap klien di Yayasan Pulih memiliki tahapan emosi yang berbeda-beda.

Kedua, Dalam proses pemulihan terdapat faktor penghambat dan pendukung untuk membantu klien. Adapun faktor itu berasal diri klien sendiri, dukungan keluarga, teman, lingkungan sosial klien dan proses pemulihan yang dijalani di Yayasan Pulih. Dampak yang terjadi pada klien seperti pendiam, pemalu, merasa bersalah, trauma terhadap sesuatu, kehilangan kepercayaan diri, tidak mudah percaya, emosional, penakut, dan menarik diri dari lingkungan sosial.

\section{Daftar Pustaka}

Amora, M. E. (2003). Perempuan, Kekerasan, dan Hukum. Yogyakarta: Press UII. Arkanto, S. (2006). Prosedur Penelitian Suatu Pendekatan Praktek. Jakarta: Rineka Cipta.

Edi Soeharto. (2008). Pendampingan Sosial dalam Pengembangan Masyarakat. Ghony, M. D., \& Almanshur, F. (2012). Metodologi Penelitian Kualitatif. Yogyakarta: Ar-Ruzz Media.

Illenis, P., \& Handadari, W. (2011). Pemulihan Diri pada Korban Kekerasan Seksual,. Jurnal of Unair, Insan Meida Psikologi, 13.

Irawan, S. (2004). Metode Penelitian Sosial, Suatu Teknik Penelitian Bidang Kesejahteraan Sosial dan Ilmu Sosial Lainnya. Bandung: Remaja Rosda Karya.

Komisi Nasional Anti Kekerasan terhadap Perempuan. (2016). Catatan Tahunan tentang kekerasan terhadap perempuan. Retrieved June 7, 2017, from https://www.komnasperempuan.go.id/reads-catatan-tahunantentang-kekerasan-terhadap- perempuan-2016.

Lexy J Moleong. (2004). Metode penelitian kualitatif. Bandung: Remaja Rosda Karya.

Soesilo, R. (1985). Kitab undang-undang hukum pidana (KUHP) serta komentarkomentarnya lengkap pasal demi pasal untuk para pejabat kepolisian negara, kejaksaan/pengadilan negeri, pamong praja dsb,. Bogor: Penerbit 
Khusnul Fadillah

\section{Politeia.}

Sub Direktorat Statistik dan Keamanan,. (2016). Statistik Kriminal 2016. Retrieved January 15, 2017, from dari www.bps.go.id/website/pdf publikasi/ statistik-kriminal-2006.pdf

Sugiyono.(2007). Metode penelitian pendidikan pendekatan kuantitatif, kualitatif dan $R \& D$. Bandung: Alfabeta.

Undang-Undang Republik Indonesia Nomor 26 Tahun 2000. (2000). Retrieved from www.dpr.go.id>dokjdih>UU_2000_26

W. Gulo. (2002). Metode Penelitian. Jakarta: PT Grasindo.

Yuryawati, N. L. A. (2010). Kajian Yuridis Tentang Pemulihan Psikologis Bagi Korban Kekerasan Terhadap Perempuan (Studi Kasus di NTB). Fakultas Hukum Universitas Mahasaraswati Mataram. 